\title{
Yessotoxin, a Promising Therapeutic Tool
}

\author{
Amparo Alfonso ${ }^{1, *}$, Mercedes R. Vieytes ${ }^{2}$ and Luis M. Botana ${ }^{2, *}$ \\ 1 Department of Pharmacology, Faculty of Veterinary, University of Santiago of Compostela, \\ 27002 Lugo, Spain \\ 2 Department of Physiology, Faculty of Veterinary, University of Santiago of Compostela, 27002 Lugo, Spain; \\ mmercedes.rodriguez@usc.es \\ * Correspondence: amparo.alfonso@usc.es (A.A.); luis.botana@usc.es (L.M.B.). Tel.: +34-982822213 (A.A.); \\ +34-982822233 (L.M.B.)
}

Academic Editor: Peer B. Jacobson

Received: 4 December 2015; Accepted: 18 January 2016; Published: 28 January 2016

\begin{abstract}
Yessotoxin (YTX) is a polyether compound produced by dinoflagellates and accumulated in filter feeding shellfish. No records about human intoxications induced by this compound have been published, however it is considered a toxin. Modifications in second messenger levels, protein levels, immune cells, cytoskeleton or activation of different cellular death types have been published as consequence of YTX exposure. This review summarizes the main intracellular pathways modulated by YTX and their pharmacological and therapeutic implications.
\end{abstract}

Keywords: yessotoxin (YTX); apoptosis; autophagy; cellular death; signal transduction; cytoskeleton; immune system; Alzheimer; glucose metabolism

\section{Introduction}

Phycotoxins are secondary metabolites produced by dinoflagellates and diatoms. Under this term, several compounds with different chemical properties, structures and mechanisms of action are included. Of these, yessotoxin (YTX) and its analogues, YTXs, are one of the most interesting groups for different reasons. YTX is an exotoxin, released by producing cells [1]. Its ecological role is unknown, and its inclusion in the list of marine toxins is due to the fact that it coexists with diarrheic toxins (okadaic acid and dinophysistoxins) and causes mice death after intraperitoneal injection, although low oral toxicity has been reported and no records about human intoxications have been reported $[2,3]$. The European Food Safety Authority (EFSA) working group on marine toxins proposed an acute reference dose (ARfD) of $25 \mu \mathrm{g}$ YTX equivalents $/ \mathrm{kg}$ body weight [4]. The European Union (EU) has recently elevated the toxin limit from 1 to $3.75 \mathrm{mg}$ of YTX equivalent $/ \mathrm{kg}$ of shellfish meat, while the limit for the other toxins within the lipophilic group is $160 \mu \mathrm{g}$ of toxin equivalent $/ \mathrm{kg}$ of shellfish meat [5]. This is a preventive measure, since, as mentioned, intoxications in humans with YTXs have never been reported. In addition, YTX is poorly absorbed after oral administration and most of the toxin is recovered from the lower intestine and feces [3]. Besides, only ultrastructural cardiac damages without other alterations were reported after oral, intraperitoneal or intravenous administrations to rats and mice [6-8]. The same effects were reported in mice after oral co-administration of YTX and okadaic acid [9] and no toxic effects were observed after oral exposure when YTX was combined with azaspiracid-1 [10]. Controversial data were published after intraperitoneal administration. In these senses, a wide range of lethal doses $\left(\mathrm{LD}_{50}\right)$ have been reported, from 80 to $750 \mu \mathrm{g} / \mathrm{kg}$, with erratic and no well-defined tissue alterations [2,8,11-15]. Therefore, YTX is a different "toxin". 


\section{YTX Origin}

YTX was first isolated in 1986 in Mutsu Bay, Japan from digestive glands of scallops Patinopecten yessoensis after a food intoxication episode [16]. Later, Protoceratium reticulatum, Lingulodinium polyedrum and Gonyaulax spinifera were identified as the dinoflagellates that produce this toxin [16-19]. In addition to Japan, YTX has been identified in shellfish harvested in Europe, including Spain, Italy, Norway, the Adriatic Sea, and Russia; Chile; and New Zealand [20,21]. The toxin has been mainly localized in immunocytes and in the digestive gland of mussels [22].

\section{YTX Chemistry}

YTXs are a group of ladder-shaped polycyclic and polyether compounds (Figure 1). YTX planar structure was first described in 1987 and the absolute configuration was reported in 1996 [16,23,24]. More than 90 analogues have been so far described, although not all have been structurally identified and isolated [25]. The chemical structure of YTXs, 11 adjacent ether rings, resembles those of other phycotoxins, such as brevetoxins, ciguatoxins or gambierone [26]. However, the cellular target of these toxins, the sodium channel, and the one for YTX are totally different. In addition, YTXs structure has an unsaturated side chain of nine carbons (C9), with different functional groups and one or more sulfate, which increase the polarity of the molecule [27]. Some YTXs are directly produced by dinoflagellates, while others are produced after shellfish metabolism. In this sense, YTX and homo YTX are produced by dinoflagellates, while 45-OH-YTX or carboxy-YTX were only isolated from shellfish [17,28,29]. In these animals, YTXs suffer extensive metabolism with a half-life of 20-24 days [30]. YTXs producing dinoflagellates coexist with those producing okadaic acid, and for this reason YTXs were considered diarrheic toxins for some years. Now, their toxicological and chemical characteristics, as well as the biogenetic origins, are better known and since it has been demonstrated that YTXs do not produce diarrhea, these toxins are considered in different groups [31,32].

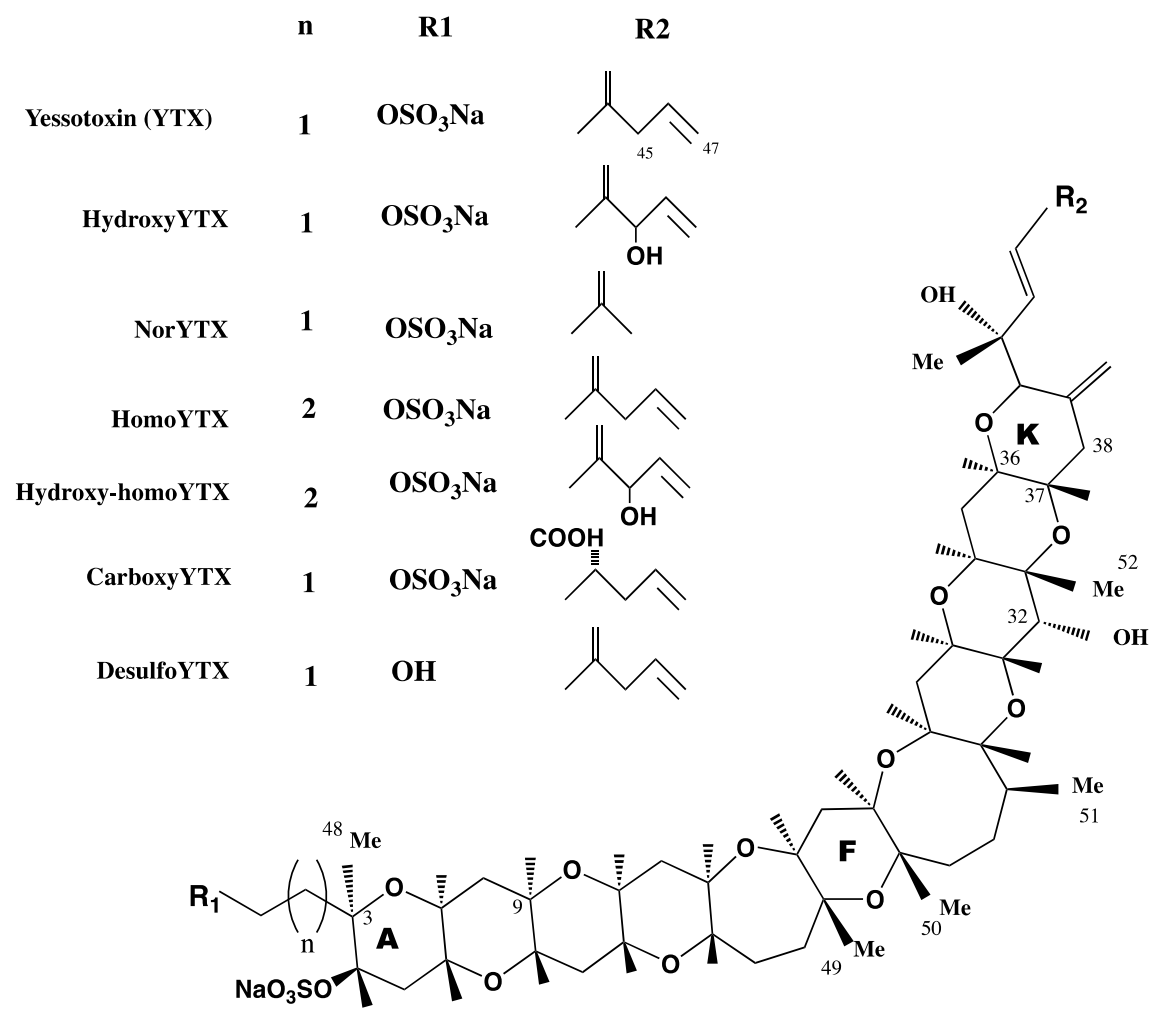

Figure 1. Structure of yessotoxins (YTXs). 


\section{Mechanism of Action of YTX}

To clarify the mechanism of action of YTXs, the modulation of several second messengers and proteins have been studied. Since YTX was considered a diarrheic toxin, first the effect on serine/threonine protein phosphatases (PP) PP1 and PP2A was checked. YTX was four times less effective than okadaic acid to inhibit these enzymes [33]. Therefore, it was concluded that YTX effect was not mediated by these phosphatases.

Depending on the cellular model, different effects in cytosolic calcium and adenosine $3^{\prime}, 5^{\prime}$-cyclic monophosphate (cAMP) levels have been reported after YTX incubation. A fast, but small, increase in cytosolic calcium levels in human fresh lymphocytes was observed. This increase was due to the activation of nifedipine and SKF 96365 sensitive calcium channels. In this cellular model, the influx of calcium through the store operated calcium channels was inhibited by YTX [34]. However, in the tumor model erythroleukemia K-562 cell line, YTX did not directly modify cytosolic calcium levels, but it increased thapsigargin-independent calcium pools depletion, as well as the influx through store operated calcium channels [35]. A cytosolic calcium increase in the presence of YTX was also observed in HL7702 human liver cells, Bel7402 human hepatoma cell line and in primary cultures of rat cerebellar neurons [36-39]. However, no direct modification in calcium basal levels was observed in rat primary cardiomyocytes after YTX incubation [40]. The effect over calcium in the K-562 cell line was related with the cAMP pathway and with the mitochondria activity [35]. In addition, permissive levels of calcium were necessary to observe the effect of YTX over the mitochondrial membrane in hepatic cells [41]. In this sense, these organelles were also affected in cardiomyocytes and neuroblastoma cells after YTX exposure [11,42]. Besides, changes in permeability of the outer mitochondrial membrane and production of pro-apoptotic factors together with swelling of mitochondria were described after incubation with YTX in myoblast cell lines [43]. Also, changes in mitochondrial membrane potential and the opening of the permeability transition pore were described after YTX exposure of hepatic cells [41].

Opposite effects were also observed in cAMP levels. In the presence of calcium, YTX dose-dependent decreased cAMP levels in human fresh lymphocytes, while a significant increase was observed in the same conditions in the K-562 cell line. These effects were calcium-dependent and also observed in guanine $3^{\prime}-5^{\prime}$ cyclic monophosphate (cGMP) levels [35,44-46]. On the other hand, YTX did not directly modify cAMP levels in rat primary cardiomyocytes, although the toxin significantly decreased the levels of this second messenger when the synthesis was activated [40].

The levels of cyclic nucleotides are regulated by phosphodiesterases (PDEs). These are a group of isozyme families with different substrate specificity, affinity, tissue localization and sensitivity to inhibitors. YTX was described to activate PDEs in human T lymphocytes in parallel with the decrease in cAMP levels. This effect was calcium dependent and modulated by PDEs activators and inhibitors [44]. The binding of YTX to PDEs was later showed within a resonant mirror biosensor where the kinetic equilibrium dissociation constant $\left(\mathrm{K}_{\mathrm{D}}\right)$ for the binding of YTXs and different PDEs was studied. In this way, $\mathrm{K}_{\mathrm{D}}(3.74 \pm 0.08 \mu \mathrm{M}$ YTX $)$ and the structure-selectivity relation of YTX-PDEs association was described [47-50]. In addition, the binding was confirmed by measuring changes in fluorescence polarization of a PDE-dye conjugate in the presence of YTX [51]. Thus, it was concluded that YTXs bind to PDE1, PDE3 and PDE4 and to exonuclease PDE I.

From all this information a relation between YTX, PDEs, calcium levels and mitochondrial conditions was concluded. The functional link between PDEs and mitochondria are the A-kinase anchor proteins (AKAPs). These are a big group of proteins that integrate PDEs and the protein kinase A (PKA), which is the kinase activated by cAMP. The cellular localization of AKAP-PDE-PKA complex is a key step in cAMP compartimentalisation signaling [52,53]. There are several AKAPs families, neuronal AKAPs such as AKAP 79, organelle-associated AKAPs such as AKAP 149 associated to the mitochondria, gravin AKAPs (AKAP 250) associated to membrane receptors and AKAP 95 associated to the nuclear matrix [54]. After YTX incubation, a significantly decrease of AKAP149 cytosolic levels in the erythroleukemia K-562 cell line was observed, which led to cell death. On the 
contrary, in fresh human lymphocytes, cytosolic AKAP149 levels were significantly increased after toxin incubation and cells survived [35]. The meaning of these results was further studied and a key role of cellular distribution of AKAP-149-PKA-PDE4A complex in YTX effect was reported. After $24 \mathrm{~h}$ of YTX exposure, the AKAP 149-PKA-PDE4A complex was located in the plasma membrane and apoptosis was activated, while after $48 \mathrm{~h}$ of YTX treatment the complex was located in the nuclear domain and non-apoptotic cellular death was observed. None of these effects were shown when AKAP-149 or PDE4A were silenced [55].

Protein kinase $\mathrm{C}(\mathrm{PKC})$ is a protein involved in multiple and different biological events and thus it plays a crucial role in cell metabolism regulation. Besides, PKC are a family of enzymes involved in pro-survival or pro-apoptotic events. Several subtypes of PKC were reported to affect some metabolic pathways activated by YTX in mice primary cortical neurons and in the mouse T lymphocyte cell line EL-4 [56,57]. PKCs modulation induced by YTX in the K-562 cell line was PDE4A-dependent, since the silencing of this protein changed PKC expression pattern [58]. However, the effect of YTX described over cortical neurons with triple transgenic mutation for Alzheimer's disease $(3 \times \mathrm{Tg}-\mathrm{AD})$ mediated by PKC was not related with PDEs or PKA [56]. This difference could be due to the lack of drug specificity or to the cellular model used.

In summary, cAMP, calcium, PDEs, PKC and AKAP-149 as well as mitochondria, are involved in the mechanism of action of YTX (Figure 2). The role of each and the final effect depend on the cellular model studied.

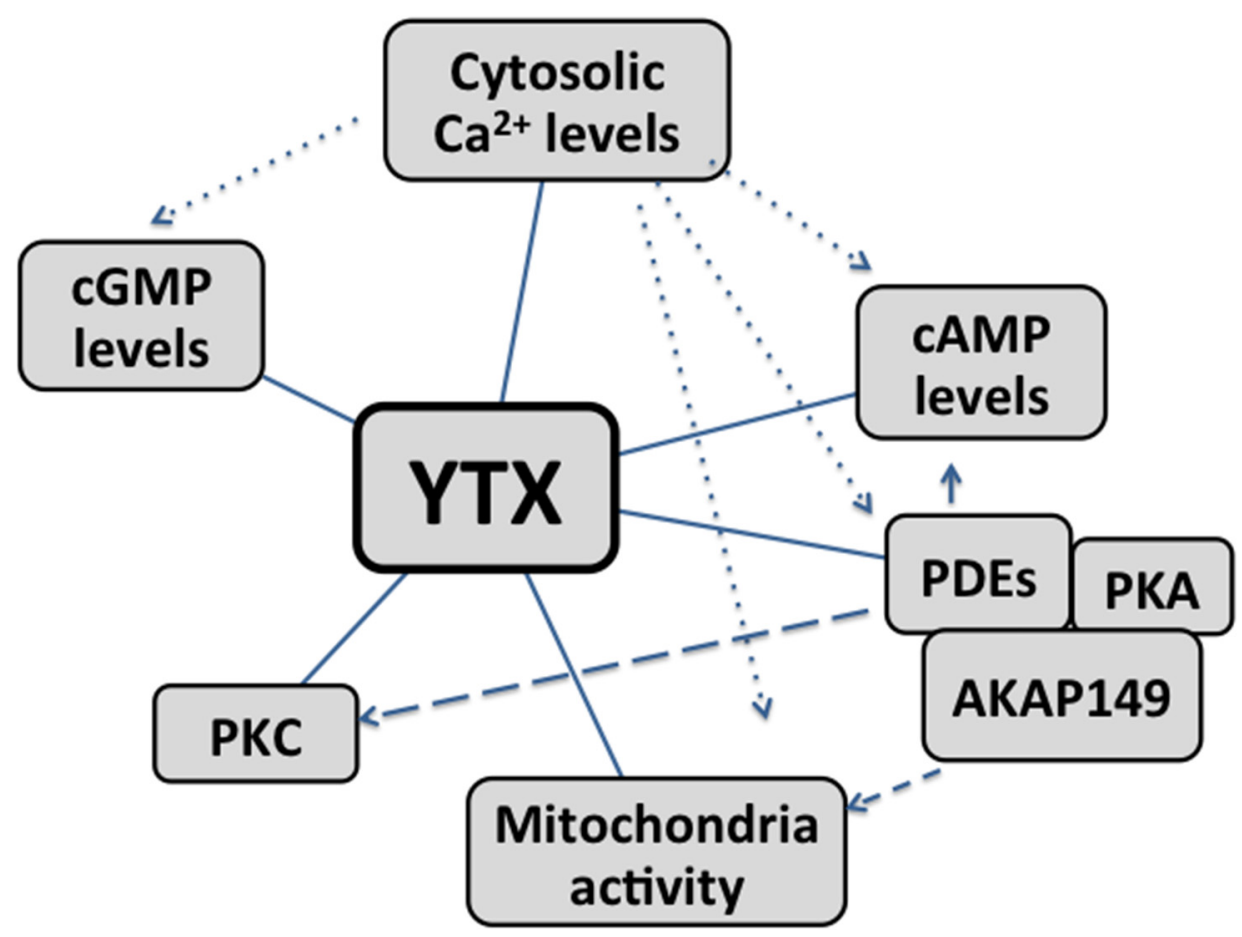

Figure 2. Cross-talks between second messengers and main intracellular organelles involved in the mechanism of action of YTX. Straight lines: pathway directly modulated by YTX. Dotted lines: Calcium levels affect YTX modulation on cGMP, cAMP, AKAP149-PKA-PDEs complex and mitochondria activity. Dashed lines: the effect of YTX is possibly mediated by the modulation of AKAP149-PKA-PDEs complex.

\section{Cellular Death and YTX}

Apoptotic and non-apoptotic cellular death were above mentioned as consequence of YTX exposure. The apoptotic effect of YTX had been reported for the first time in 2002 in BE(2)-M17 neuroblastoma cell line [42]. Later, several apoptosis hallmarks in many different cell types, such 
as HeLa $\mathrm{S}_{3}$ cells, cerebellar neurons, L6 and BC3H1 myoblasts, mouse fibroblasts NIH3T3, MDCK kidney cells and MCF-7 breast cells, HepG2, Bel7402 and HL7702 human hepatoma cell lines, and liver cells have been published [37-39,43,59-64]. In the erythroleukemia K-562 cell line the apoptotic cell death was activated after $24 \mathrm{~h}$ YTX incubation when the AKAP 149-PKA-PDE4A complex was located in the plasma membrane [55]. In these cells, variations of both intrinsic (Bcl2 and caspases 3) and extrinsic (caspase 8) apoptotic hallmarks had been showed after $24 \mathrm{~h}$ of YTX incubation, indicating the activation of these two types of apoptotic cell death [55,65]. After YTX exposure, no external ligands to activate death-inducing signaling complex (DISC) were described [66]. Therefore the increase of caspase 8 activity, and as consequence the activation of extrinsic apoptosis, may be mediated by the activation of internal receptors (Fas receptor) through the light chain-3B-II (LC3B-II) protein increased after $24 \mathrm{~h}$ of YTX exposure [67]. The non-apoptotic programed cell death activated by YTX after $48 \mathrm{~h}$ incubation, when the complex was located in the nuclear domain, was described as autophagy [67]. This programmed cell death activated by the toxin was also indicated in human glioma cells as a consequence of endoplasmic reticulum-stress, cell cycle arrest in G1 and inhibition of protein synthesis [68]. This last effect was also observed in myoblast cells, and YTX was proposed as a ribotoxin [69]. In K-562 cells, the YTX-activated autophagy was dependent of PDE4A but independent of PKC [58,67]. In addition to apoptosis and autophagy, paraptosis, a cytoplasm caspase-independent death mechanism, was also described after YTX and 1-desulfoYTX incubations [70,71]. This process was described in BC3H1 myoblast cell lines, as independent of caspases, and causing extensive cytoplasmic vacuolation, changes (swelling) in mitochondria and endoplasmic reticulum (ER), no DNA fragmentation and activation of mitogen-activated protein kinases (MAP kinase). Considering all these data about death activation, YTX is one of the few compounds reported to induce cell death by all three mechanisms, apoptosis, paraptosis and autophagy (Figure 3). Thus, as it was proposed, this compound is a valuable tool to study multiple death pathways [72].

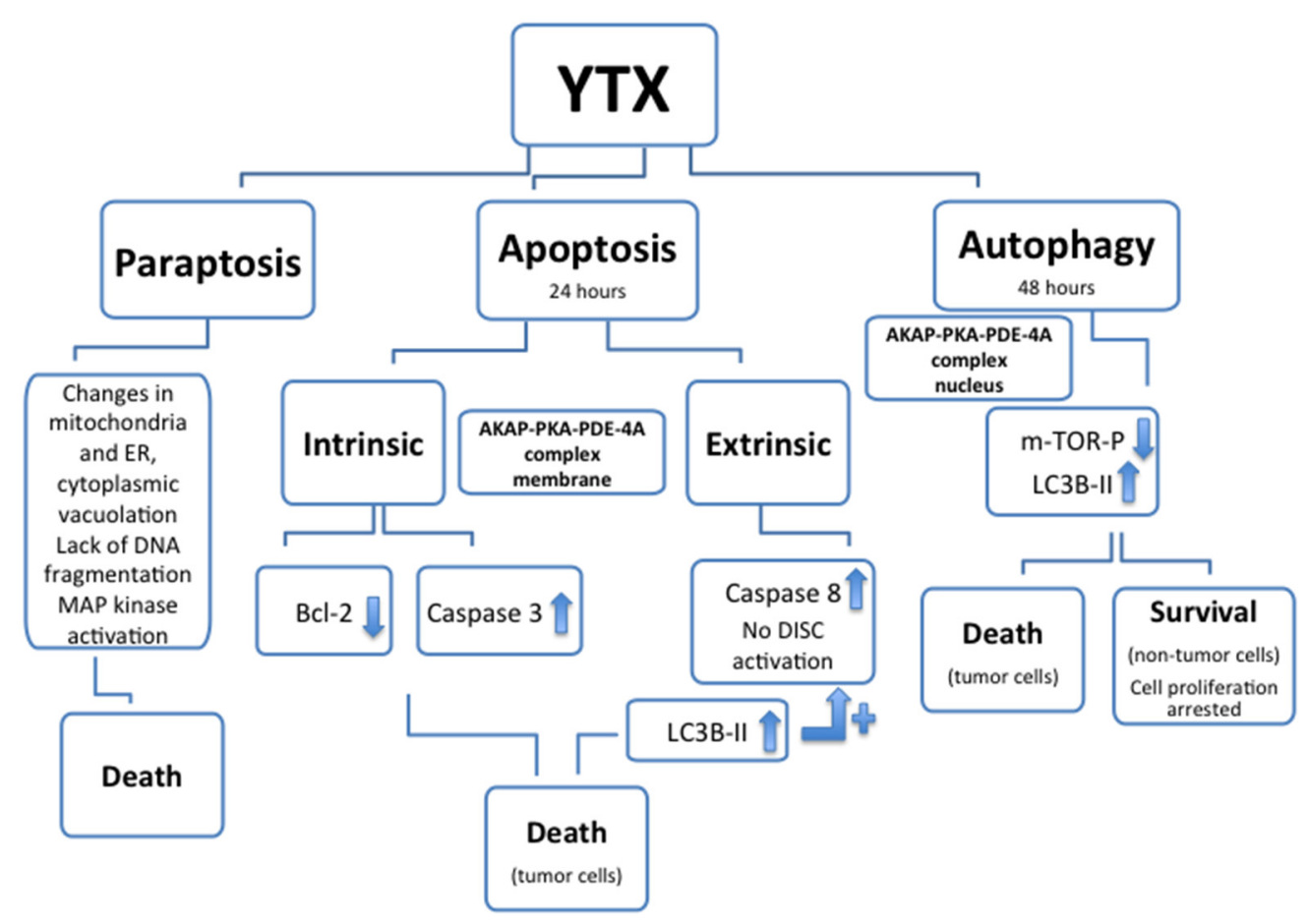

Figure 3. Cellular death types (paraptosis, apoptosis and autophagy) and associated hallmarks affected after YTX treatment. In some cellular models, after YTX treatment, autophagy is activated and cellular proliferation arrested, however no cellular death is associated. 
The potential of YTX to induce cell death was checked in the 58 cell lines of the National Cancer Institute human tumor cell line screen [73]. From these results, high toxicity of YTX, in the nanomolar range, was observed on 27 of 58 cellular lines checked after $48 \mathrm{~h}$ incubation. High YTX sensitivity was observed in tumor lines from melanoma, seven affected of eight tested; lung, seven of nine; colon, five of seven; and leukemia, three of five. Medium sensitivity was reported in mammary tumor lines, three of seven. Low sensitivity in tumor lines from ovarian, one of six; renal, one of eight; central nervous system, one of six; and prostate, zero of two was also reported [73]. Reduction of cell viability was also reported in primary rat cardiomyocytes after YTX exposure [40]. However, no acute effects on cellular viability had been observed in non-tumor cells such as primary cerebellar mouse neurons, fresh human lymphocytes and fresh rabbit enterocytes after treatment with concentrations of YTX highly toxic for other cells $[35,45,74]$. On the contrary, high toxic effects were reported in fresh cortical mice neurons and in long cultured rat cerebellar neurons $[39,56]$. The effect in cell viability was further studied in a lymphoblastoid cell line. This is a non-tumor model with normal apoptotic and mitotic machinery [65]. Again, opposite to tumor models, no cell death activation was observed in these cells after 24 or $48 \mathrm{~h}$ in the presence of YTX. In this sense, variations in apoptosis hallmarks were not detected in the lymphoblastoid cell line after YTX incubation. On the contrary, some autophagy hallmarks were modified after $48 \mathrm{~h}$ of toxin incubation that converged into decrease in cellular proliferation, while no cell death was observed. Thus, YTX treatment triggered autophagy cell death in K-526 cells while in lymphoblastoid cells the toxin stops cellular proliferation. These YTX effects were related to PDE4A in both cellular lines. Therefore, the dual effect of YTX over tumor and non-tumor cells point to this compound as a powerful antitumoral drug or at least as a good drug lead [75,76]. In this sense, AKAP 149 protein is essential for mitosis [77-79], hence those factors that prevent the activity of this protein cause cell death, as in the case of YTX in K-526 cells. This line of reasoning based on AKAP 149 would explain the differences in response between normal and tumor cells to YTX. Indeed, surprisingly different molecular weights for PDE4A proteins were observed depending on the cellular model, $80 \mathrm{kDa}$ in the case of K-562 cells, and $98 \mathrm{kDa}$, the normal molecular weight for this protein, in the lymphoblastoid cells [65]. In this sense, tumor cells have protein mutations that could lead to the change in the protein function, and these mutations are sometimes used as tumor biomarkers [80]. Therefore, YTX seems to be a specific cellular death inductor of tumor cells independently of their mitotic ability although the proliferation rate can be essential to explain YTX cellular resistance [68]. The variations of YTX effects over cell viability depending on the cellular model tested are shown in Table 1 (non-tumor cells), Table 2 and Figure 4 (tumor cells).

Table 1. YTX effects in non-tumor cells.

\begin{tabular}{ccc}
\hline Cellular Model & Effect (YTX Concentration and Incubation Time) & Reference \\
\hline Fresh enterocytes (rabbit) & No effect on F-actin $(1 \mu \mathrm{M}, 4 \mathrm{~h})$ & {$[74]$} \\
\hline Long cultured cerebellar neurons (rat) & Actin decrease, Apoptosis (5-150 $\mathrm{nM}, 48 \mathrm{~h})$ & {$[39]$} \\
\hline Primary cardiomyocytes (rat) & $\begin{array}{c}\text { Irreversible reduction of cell viability } \\
(>10 \mathrm{nM}, 48 \mathrm{~h})\end{array}$ & {$[40]$} \\
\hline Primary cerebellar neurons (mouse) & $\begin{array}{c}\text { No cellular death }(1 \mu \mathrm{M}, 48 \mathrm{~h})(50 \mu \mathrm{M}, 48 \mathrm{~h}, 70 \% \\
\text { cellular death) }\end{array}$ & {$[45]$} \\
\hline MDCK kidney cells (dog) & $\begin{array}{c}\text { Cellular Death Accumulation of E-cadherin } \\
\text { fragment ECRA100 }(1 \mathrm{nM}, 21 \mathrm{~h})\end{array}$ & {$[62]$} \\
\hline Fresh lymphocytes (human) & $\begin{array}{c}\text { No effect on cell viability }(1 \mu \mathrm{M}, 48 \mathrm{~h}) \\
\text { Lymphoblastoid cell line (human) }\end{array}$ & $\begin{array}{c}\text { No effect on cell viability }(30 \mathrm{nM}, 24 \mathrm{~h}, \mathrm{no} \\
\text { proliferation but no death) }\end{array}$ \\
\hline Fresh cortical neurons (mouse) & Cellular death (1-100 $\mathrm{nM}, 48 \mathrm{~h})$ & {$[65]$} \\
\hline
\end{tabular}


Table 2. Cellular lines showing different cellular death-types and effects induced by YTX.

\begin{tabular}{|c|c|c|}
\hline Cellular Model & Effect & Reference \\
\hline Rat glioma cells & Cell detachment and cytotoxicity & [33] \\
\hline BE(2)-M17 human neuroblastoma cells & Apoptosis & [42] \\
\hline HeLa $S_{3}$ human cervix adenocarcinoma cells & Cellular death Apoptotic hallmarks & [59] \\
\hline L6 and $\mathrm{BC} 3 \mathrm{H} 1$, rat and mouse skeletal myoblasts & Cytoskeleton disruption Apoptosis & {$[43,60,81]$} \\
\hline NIH3T3 mouse fibroblasts & $\begin{array}{l}\text { Lysosomal damage, which may suggest } \\
\text { autophagy }\end{array}$ & [61] \\
\hline Bel7402 human hepatoma cells & Apoptosis & {$[36,38]$} \\
\hline MCF-7 human breast adenocarcinoma cells & $\begin{array}{c}\text { Cellular Death Accumulation of E-cadherin } \\
\text { fragment ECRA100 }\end{array}$ & {$[62,63]$} \\
\hline $\begin{array}{l}\text { A2780 human ovarian carcinoma and HeLa229 human } \\
\text { cervix carcinoma cells }\end{array}$ & Cellular death & [45] \\
\hline Hep G2 human hepatocellular cells & Apoptosis & [64] \\
\hline BC3H1 myoblast cells & Paraptosis & [70] \\
\hline Mouse T-lymphocytes EL-4 cells & Disruption of F-actin cytoskeleton Apoptosis & [82] \\
\hline HL7702 human hepatoma cells & Apoptosis & [37] \\
\hline Human Erythroleukemia K-562 cells & Apoptosis and autophagy & {$[55,67]$} \\
\hline Human glioma cells & Autophagy & [68] \\
\hline Mammary tumor lines MDA-MB-231, MCF-7, T-47D & Cellular death & [73] \\
\hline Ovarian tumor lines OVCAR-3 & Cellular death & [73] \\
\hline $\begin{array}{l}\text { Lung tumor lines A-549, HOP-92, EKVX, HOP-62, } \\
\text { NCI-H23, NCI-H522, NCI-H460, MSTO-211H }\end{array}$ & Cellular death & [73] \\
\hline Renal tumor lines UO-31 & Cellular death & [73] \\
\hline Central nervous system tumor lines SF-295 & Cellular death & [73] \\
\hline $\begin{array}{c}\text { Melanoma line MALME-3M, SK-MEL-28, SK-MEL-2, } \\
\text { SK-MEL-5, UACC-257, UACC-62, M-14 }\end{array}$ & Cellular death & [73] \\
\hline $\begin{array}{l}\text { Colon tumor lines KM-12, COLO-205, HT-29, SW-620, } \\
\text { HCT-116 }\end{array}$ & Cellular death & [73] \\
\hline Leukemia lines K-562, SR, CCRF-CEM & Cellular death & [73] \\
\hline Pancreas tumor lines BxPC-3 & Cellular death & [73] \\
\hline
\end{tabular}

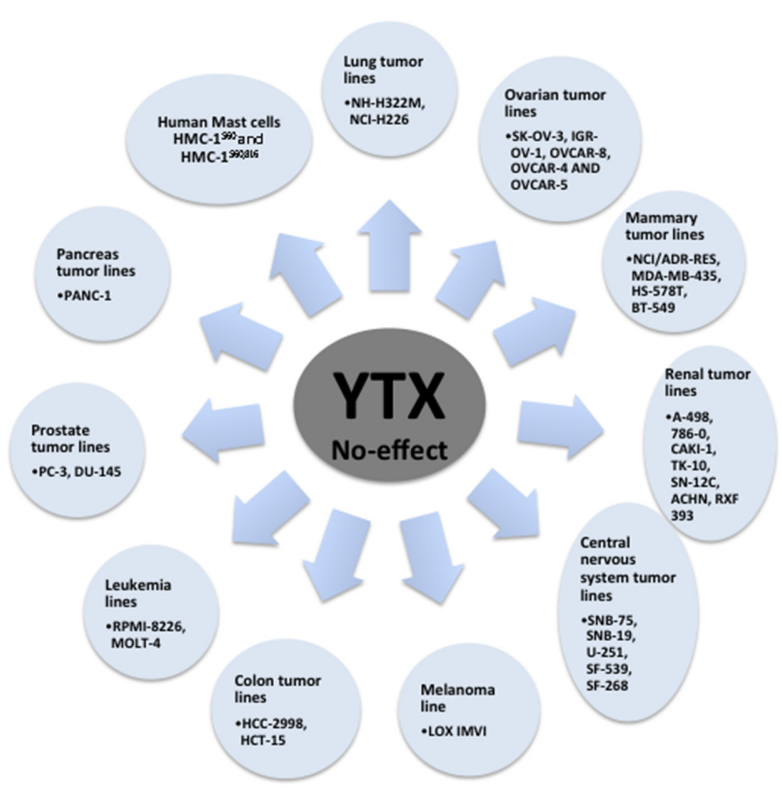

Figure 4. Summary of cellular lines no affected by YTX treatment [73]. 


\section{Cytoskeleton and Cell Adhesion and YTX}

After YTX incubation, cells detachment from culture dishes was observed [33,42]. However, no modifications in F-actin were reported, both in neuroblastoma BE(2)-M17 cells and rabbit fresh enterocytes, after $1 \mathrm{~h}$ or $4 \mathrm{~h}$ of $1 \mu \mathrm{M}$ YTX exposure [74,83]. On the contrary, lysosomal vesicles, and progressive depolymerization of actin microfilaments were described as events activated after YTX exposure of insect fat body IPLB-LdFB cells, mouse fibroblasts NIH3T3 cell lines and cultured rat cerebellar neurons $[12,39,61]$. In addition, disassemble of F-actin and translocation of tensin during cytoskeleton disruption was described after $72 \mathrm{~h}$ YTX treatment when apoptosis was activated in L6 and BC3H1 myoblast cell lines [81]. Disruption of F-actin cytoskeleton was also observed in mouse T-lymphocytes EL-4 cells after $48 \mathrm{~h}$ of incubation the presence of YTX associated to apoptosis activation [82]. However, as it was mentioned only ultrastructural cardiac damages without other cellular alterations were reported after in vivo administration of YTX to rats and mice [6-8].

E-cadherin is a large family of proteins responsible for calcium-dependent cell-to-cell adhesion. This protein mediates in the aggregation-dependent cell survival. A decrease in E-cadherin expression is usually associated with the tumor expansion in epithelial cells, but also the protein has a role in survival and apoptosis suppression in other carcinoma cells [84]. E-cadherin collapse, with accumulation of a $100 \mathrm{kDa}$ fragment of E-cadherin, without a parallel loss of the intact protein, was described after YTX incubation of human breast cancer cells MCF-7 and Caco-2 cells $[85,86]$. This effect was structure-selective and dependent on C9 chain [87]. In this sense, the same structure-selectivity relationship was observed in the association of PDEs and YTX analogs [49]. However, no in vivo effects over E-cadherin disruption were observed after mouse oral administration and E-cadherin stabilization in mouse colon cells was observed [88]. These contradictory in vitro and in vivo effects were later explained as an effect of YTX on E-cadherin degradation pathway, which is affected by the cellular context [62]. Therefore, again, different results were reported after YTX exposure depending on the cellular model.

\section{Immune System and YTX}

YTX has been reported to have an immune-regulatory effect on T-lymphocyte EL-4 cells by reversible down-regulation of the $T$ cell receptor complex due to activation of $[57,82]$. On the other hand, as happens with drugs that decrease the levels of cAMP, YTX had increased the release of IL-2 in fresh human T cells [44]. In this sense, the release of cytokines such as TNF- $\alpha$, was also activated by YTX in the murine macrophage cell line J774, and the toxin reduced the phagocytic activity and phagosome maturation of mouse peritoneal macrophages [89]. On the other hand, an increase in mussel phagocytic immunocytes was described under control conditions after YTX addition, but no effect was reported under stress conditions [12,90]. Indeed, shape changes in mussel immunocytes were detected after toxin exposure and although these cells were no activated, an increase in the active response of other activators was reported. In this effect, both extracellular calcium and cAMP were involved [12,91]. After mice intraperitoneal injection, structural damages in the thymus and variations in immune cells have been described [12]. Therefore either in mammalian or shellfish, YTX has some relation with the immune system and/or the immune response. In this sense, cAMP/PKA/PDEs pathway has a key role in cellular activation of inflammatory cells such as mast cells [92]. In this sense, YTX effect was also checked in fresh rat mast cells and in the Human Mast Cell lines HMC-1 ${ }^{560}$ and HMC-1 ${ }^{560,816}$. Mast cells are non-excitable mononucleated cells, mainly involved in episodes of inflammation and immune response. These cells are well known models frequently used in studies of immune response. The activation of mast cells induced after immunological stimulation was highly inhibited in the presence of YTX [93]. Besides in HMC-1 cell lines, inhibition of cellular stimulation and no modifications in cellular viability after $48 \mathrm{~h}$ incubation in the presence of YTX (1-100 nM) were observed (unpublished results). All these data point to YTX as an interesting tool in allergy processes [93]. 


\section{Alzheimer's Disease and YTX}

An interesting pharmacological effect over Alzheimer's cellular pathology had been described after YTX treatment. As was mentioned, YTX in the in vitro model of Alzheimer's disease, primary cortical neurons 3xTg-AD, showed an improvement of Tau and $\beta$-amyloid levels through a mechanism related to the activation and translocation to the plasma membrane of cytosolic PKC. In this sense, it is known that patients with Alzheimer's disease have reduced PKC levels [94]. Again, different response was observed depending on the cellular model. The response to YTX in primary transgenic neurons with three mutations and primary normal neurons was different regarding to PDE4. YTX increased $65 \%$ PDE4 levels in normal neurons, and no modifications in PDE4 levels were observed in transgenic neurons. In addition, in neurons, cAMP levels were not modified in the presence of YTX [56]. Moreover, from all these data, the effect of YTX in Alzheimer's neurons is closer to therapy than to toxicology [95].

\section{Glucose Metabolism and YTX}

Important transcriptional changes on the lipids and glucose metabolism have been described after YTX treatment of glioma cells $[68,73]$. Alterations in pancreas and liver, with fatty degeneration were reported earlier as consequence of di-desulfo-YTX exposure [15]. A deregulation of lipid metabolism induced by the toxins was observed in glioma cells as consequence of endoplasmic reticulum stress. This effect translates into an increase in cholesterol content. This increase may justify the increase in cytosolic calcium produced by the toxin. The stress induced is also related to an increase in mitochondrial metabolism [68]. From these experiments, YTX was proposed as a lead molecule to treat and/or prevent metabolic diseases [96].

\section{Conclusions}

As shown in this review, YTX has multiple effects and therefore is a powerful tool to study different intracellular pathways (Figure 5). Since different, and sometimes contradictory, effects were observed depending on the cellular model, it is very difficult to confirm that this compound is only a toxin. However, it is a helpful drug for pharmacological approaches, besides some of the YTX effects are potentially useful with therapeutic proposals.

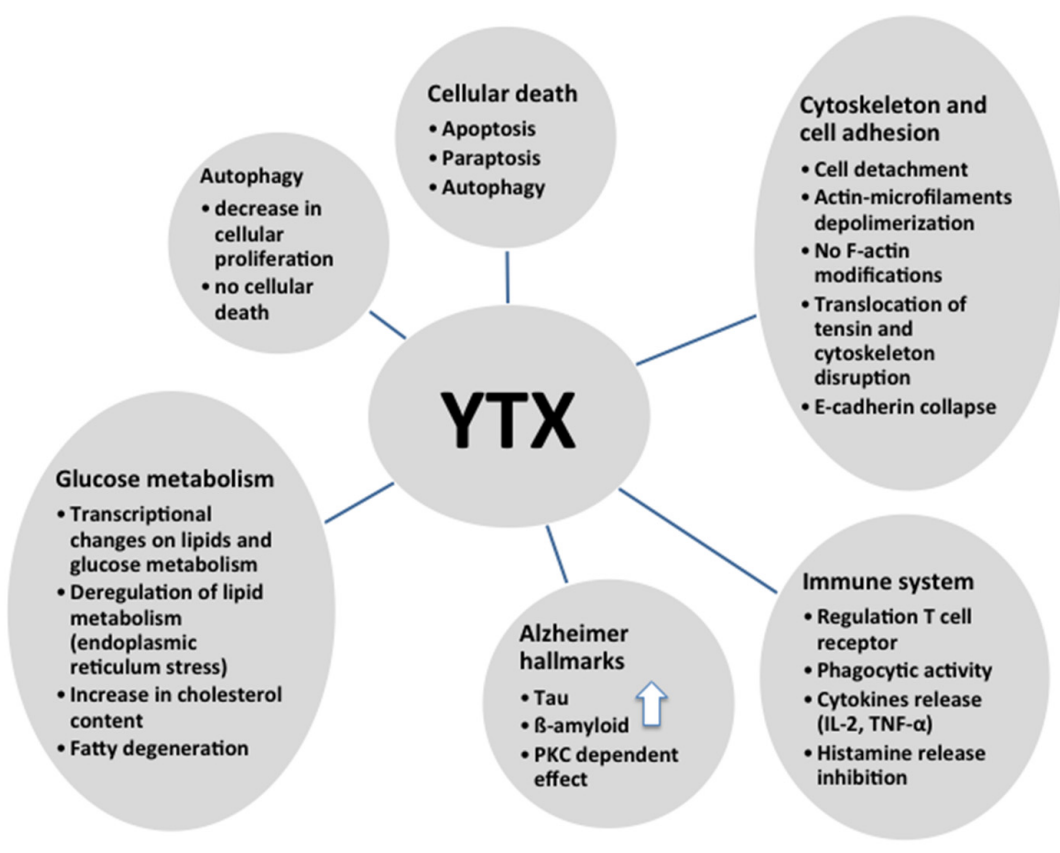

Figure 5. Summary of different effects of YTX. 
Acknowledgments: The research leading to these results has received funding from the following FEDER cofunded grants. From CDTI and Technological Funds, supported by Ministerio de Economía y Competitividad, AGL2012-40185-CO2-01, AGL2014-58210-R; Consellería de Cultura, Educación e Ordenación Universitaria, GRC2013-016; CDTI under ISIP Programme, Spain, IDI-20130304 APTAFOOD; and the European Union's Seventh Framework Programme managed by REA-Research Executive Agency (FP7/2007-2013) under grant agreement 312184 PHARMASEA.

Conflicts of Interest: The authors declare no conflict of interest.

\section{References}

1. Hess, P.; Aasen, J. Chemistry, origins and distribution of Yessptoxinand its analogues. In Phycotoxins, Chemistry and Biochemistry; Botana, L.M., Ed.; Blackwell Publishing: Ames, IA, USA, 2007; pp. 187-202.

2. Aune, T.; Sorby, R.; Yasumoto, T.; Ramstad, H.; Landsverk, T. Comparison of oral and intraperitoneal toxicity of yessotoxin towards mice. Toxicon 2002, 40, 77-82. [CrossRef]

3. Munday, R.; Aune, T.; Rossini, J.P. Toxicology of the yessotoxins. In Seafood and Freshwater Toxins, 2nd ed.; Botana, L.M., Ed.; CRC Press, Taylor and Francis Group: London, UK, 2008; pp. 371-380.

4. EFSA. Marine biotoxins in shellfish-Yessotoxin group. Scientific opinion of the panel on contaminants in the food chain. Eur. Food Saf. Auth. J. 2008, 907, 1-62.

5. EU. Commission Regulation (EU) No. 786/2013 of 16 August 2013 amending Annex III to Regulation (EC) No. 853/2004 of the European Parliament and of the Council as regards the permitted limits of yessotoxins in live bivalve molluscs. Off. J. Eur. Union 2013, L220, 14.

6. Ferreiro, S.F.; Carrera, C.; Vilarino, N.; Louzao, M.C.; Santamarina, G.; Cantalapiedra, A.G.; Botana, L.M. Acute cardiotoxicity evaluation of the marine biotoxins OA, DTX-1 and YTX. Toxins 2015, 7, 1030-1047. [CrossRef] [PubMed]

7. Tubaro, A.; Giangaspero, A.; Ardizzone, M.; Soranzo, M.R.; Vita, F.; Yasumoto, T.; Maucher, J.M.; Ramsdell, J.S.; Sosa, S. Ultrastructural damage to heart tissue from repeated oral exposure to yessotoxin resolves in 3 months. Toxicon 2008, 51, 1225-1235. [CrossRef] [PubMed]

8. Tubaro, A.; Dell'ovo, V.; Sosa, S.; Florio, C. Yessotoxins: A toxicological overview. Toxicon 2010, 56, $163-172$. [CrossRef] [PubMed]

9. Sosa, S.; Ardizzone, M.; Beltramo, D.; Vita, F.; Dell'Ovo, V.; Barreras, A.; Yasumoto, T.; Tubaro, A. Repeated oral co-exposure to yessotoxin and okadaic acid: A short term toxicity study in mice. Toxicon 2013, 76, 94-102. [CrossRef] [PubMed]

10. Aasen, J.A.; Espenes, A.; Miles, C.O.; Samdal, I.A.; Hess, P.; Aune, T. Combined oral toxicity of azaspiracid-1 and yessotoxin in female NMRI mice. Toxicon 2011, 57, 909-917. [CrossRef] [PubMed]

11. Tubaro, A.; Sosa, S.; Carbonatto, M.; Altinier, G.; Vita, F.; Melato, M.; Satake, M.; Yasumoto, T. Oral and intraperitoneal acute toxicity studies of yessotoxin and homoyessotoxins in mice. Toxicon 2003, 41, 783-792. [CrossRef]

12. Franchini, A.; Malagoli, D.; Ottaviani, E. Targets and effects of yessotoxin, okadaic acid and palytoxin: A differential review. Mar. Drugs 2010, 8, 658-677. [CrossRef] [PubMed]

13. Franchini, A.; Marchesini, E.; Poletti, R.; Ottaviani, E. Lethal and sub-lethal yessotoxin dose-induced morpho-functional alterations in intraperitoneal injected Swiss CD1 mice. Toxicon 2004, 44, 83-90. [CrossRef] [PubMed]

14. Franchini, A.; Marchesini, E.; Poletti, R.; Ottaviani, E. Acute toxic effect of the algal yessotoxin on Purkinje cells from the cerebellum of Swiss CD1 mice. Toxicon 2004, 43, 347-352. [CrossRef] [PubMed]

15. Terao, K.; Ito, E.; Oarada, M.; Murata, M.; Yasumoto, T. Histopathological studies on experimental marine toxin poisoning-5. The effects in mice of yessotoxin isolated from Patinopecten yessoensis and of a desulfated derivative. Toxicon 1990, 28, 1095-1104. [CrossRef]

16. Murata, M.; Kumagai, M.; Lee, J.S.; Yasumoto, T. Isolation and structure of yessotoxin, a novel polyether compound implicated in diarrhetic shellfish poisoning. Tetrahedron Lett. 1987, 28, 5869-5872. [CrossRef]

17. Miles, C.O.; Wilkins, A.L.; Hawkes, A.D.; Selwood, A.I.; Jensen, D.J.; Munday, R.; Cooney, J.M.; Beuzenberg, V. Polyhydroxylated amide analogs of yessotoxin from Protoceratium reticulatum. Toxicon 2005, 45, 61-71. [CrossRef] [PubMed] 
18. Paz, B.; Riobo, P.; Fernandez, M.L.; Fraga, S.; Franco, J.M. Production and release of yessotoxins by the dinoflagellates Protoceratium reticulatum and Lingulodinium polyedrum in culture. Toxicon 2004, 44, 251-258. [CrossRef] [PubMed]

19. Rhodes, L.; McNabb, P.; de Salas, M.; Briggs, L.; Beuzenberg, V.; Gladstone, M. Yessotoxin production by Gonyaulax spinifera. Harmful Algae 2006, 5, 148-155. [CrossRef]

20. Tubaru, A.; Sidari, L.; Della Loggia, R.; Yasumoto, T. Occurrence of yessotoxin-like toxins in phytoplankton and mussels from Northern Adriatic Sea, Vigo, Spain, 1997. In Proceedings of the VIII International Conference on Harmful Algae, Santiago de Compostela, Spain, 25-29 June 1997; Reguera, B., Blanco, J., Fernández, M.L., Wyatt, T., Eds.; Xunta de Galicia and Intergovernmental Oceanographic Commission of UNESCO: Santiago de Compostela, Spain, 1998.

21. Paz, B.; Daranas, A.H.; Norte, M.; Riobo, P.; Franco, J.M.; Fernandez, J.J. Yessotoxins, a group of marine polyether toxins: An overview. Mar. Drugs 2008, 6, 73-102. [CrossRef] [PubMed]

22. Franchini, A.; Milandri, A.; Poletti, R.; Ottaviani, E. Immunolocalization of yessotoxins in the mussel Mytilus galloprovincialis. Toxicon 2003, 41, 967-970. [CrossRef]

23. Satake, M.; Terasawa, K.; Kadowaki, Y.; Yasumoto, T. Relative configuration of yessotoxin and isolation of two new analogs from toxic scallops. Tetrahedron Lett. 1996, 37, 5955-5958. [CrossRef]

24. Takahashi, H.; Kusumi, T.; Kan, Y.; Satake, M.; Yasumoto, T. Determination of the absolute configuration of yessotoxin, a polyether compound implicated in diarrhetic shellfish poisoning, by NMR spectroscopic method using a chiral anisotropic reagent, methoxy-(2-naphthyl)acetic acid. Tetrahedron Lett. 1996, 37, 7087-7090. [CrossRef]

25. Miles, C.O.; Samdal, I.A.; Aasen, J.; Jensen, D.J.; Quilliam, M.A.; Petersen, D.; Briggs, L.M.; Wilkins, A.L.; Rise, F.; Cooney, J.M.; et al. Evidence for numerous analogs of yessotoxin in Protoceratium reticulatum. Harmful Algae 2005, 4, 1075-1091. [CrossRef]

26. Rodriguez, I.; Genta-Jouve, G.; Alfonso, C.; Calabro, K.; Alonso, E.; Sanchez, J.A.; Alfonso, A.; Thomas, O.P.; Botana, L.M. Gambierone, a ladder-shaped polyether from the dinoflagellate gambierdiscus belizeanus. Org. Lett. 2015, 17, 2392-2395. [CrossRef] [PubMed]

27. Yasumoto, T.; Takizawa, A. Fluorometric measurement of yessotoxins in shellfish by high-pressure liquid chromatography. Biosci. Biotechnol. Biochem. 1997, 61, 1775-1777. [CrossRef] [PubMed]

28. Miles, C.O.; Wilkins, A.L.; Jensen, D.J.; Cooney, J.M.; Quilliam, M.A.; Aasen, J.; MacKenzie, A.L. Isolation of 41a-homoyessotoxin and the identification of 9-methyl-41a-homoyessotoxin and nor-ring A-yessotoxin from Protoceratium reticulatum. Chem. Res. Toxicol. 2004, 17, 1414-1422. [CrossRef] [PubMed]

29. Satake, M.; Tubaro, A.; Lee, J.S.; Yasumoto, T. Two new analogs of yessotoxin, homoyessotoxin and 45-hydroxyhomoyessotoxin, isolated from mussels of the Adriatic Sea. Nat. Toxins 1997, 5, 107-110. [CrossRef] [PubMed]

30. Aasen, J.; Samdal, I.A.; Miles, C.O.; Dahl, E.; Briggs, L.R.; Aune, T. Yessotoxins in Norwegian blue mussels (Mytilus edulis): Uptake from Protoceratium reticulatum, metabolism and depuration. Toxicon 2005, 45, 265-272. [CrossRef] [PubMed]

31. Draisci, R.; Lucentini, L.; Mascioni, A. Enteric toxic episodes. Pectenotoxins and yessotoxins: Chemistry, toxicology, pharmacology and analysis. In Seafood and Freshwater Toxins: Pharmacology, Physiology and Detection; Botana, L.M., Ed.; Marcel Dekker: New York, NY, USA, 2000; pp. 289-324.

32. Tubaro, A.; Sosa, S.; Altinier, G.; Soranzo, M.R.; Satake, M.; Della Loggia, R.; Yasumoto, T. Short-term oral toxicity of homoyessotoxins, yessotoxin and okadaic acid in mice. Toxicon 2004, 43, 439-445. [CrossRef] [PubMed]

33. Ogino, H.; Kumagai, M.; Yasumoto, T. Toxicological evaluation of yessotoxin. Nat. Toxins 1997, 5, $255-259$. [CrossRef]

34. De la Rosa, L.A.; Alfonso, A.; Vilariño, N.; Vieytes, M.R.; Botana, L.M. Modulation of cytosolic calcium levels of human lymphocytes by yessotoxin, a novel marine phycotoxin. Biochem. Pharmacol. 2001, 61, 827-833. [CrossRef]

35. Tobío, A.; Fernández-Araujo, A.; Alfonso, A.; Botana, L.M. Role of yessotoxin in calcium and cAMP-crosstalks in primary and K-562 human lymphocytes: The effect is mediated by Anchor kinase a mitochondrial proteins. J. Cell. Biochem. 2012, 113, 3752-3761. [CrossRef] [PubMed]

36. Pang, M.; Qu, P.; Gao, C.L.; Tang, X.; Wang, Z.L. Effect of yessotoxin on cytosolic calcium levels in human hepatocellular carcinoma cells. Biomed. Rep. 2014, 2, 93-96. [CrossRef] [PubMed] 
37. Pang, M.; Qu, P.; Gao, C.L.; Wang, Z.L. Yessotoxin induces apoptosis in HL7702 human liver cells. Mol. Med. Rep. 2012, 5, 211-216. [CrossRef] [PubMed]

38. Pang, M.; Wang, Z.L.; Gao, C.L.; Qu, P.; Li, H.D. Characterization of apoptotic changes induced by yessotoxin in the Bel7402 human hepatoma cell line. Mol. Med. Rep. 2011, 4, 547-552. [PubMed]

39. Perez-Gomez, A.; Ferrero-Gutierrez, A.; Novelli, A.; Franco, J.; Paz, B.; Fernandez-Sanchez, M.T. Potent neurotoxic action of the shellfish biotoxin yessotoxin on cultured cerebellar neurons. Toxicol. Sci. 2006, 90, 168-177. [CrossRef] [PubMed]

40. Dell'Ovo, V.; Bandi, E.; Coslovich, T.; Florio, C.; Sciancalepore, M.; Decorti, G.; Sosa, S.; Lorenzon, P.; Yasumoto, T.; Tubaro, A. In vitro effects of yessotoxin on a primary culture of rat cardiomyocytes. Toxicol. Sci. 2008, 106, 392-399. [CrossRef] [PubMed]

41. Bianchi, C.; Fato, R.; Angelin, A.; Trombetti, F.; Ventrella, V.; Borgatti, A.R.; Fattorusso, E.; Ciminiello, P.; Bernardi, P.; Lenaz, G.; et al. Yessotoxin, a shellfish biotoxin, is a potent inducer of the permeability transition in isolated mitochondria and intact cells. Biochim. Biophys. Acta 2004, 1656, 139-147. [CrossRef] [PubMed]

42. Leira, F.; Alvarez, C.; Vieites, J.M.; Vieytes, M.R.; Botana, L.M. Characterization of distinct apoptotic changes induced by okadaic acid and yessotoxin in the BE(2)-M17 neuroblastoma cell line. Toxicol. Vitro 2002, 16, 23-31. [CrossRef]

43. Korsnes, M.S.; Hetland, D.L.; Espenes, A.; Tranulis, M.A.; Aune, T. Apoptotic events induced by yessotoxin in myoblast cell lines from rat and mouse. Toxicol. Vitro 2006, 20, 1077-1087. [CrossRef] [PubMed]

44. Alfonso, A.; de la Rosa, L.A.; Vieytes, M.R.; Yasumoto, T.; Botana, L.M. Yessotoxin a novel phycotoxin, activates phosphodiesterase activity. Effect of yessotoxin on cAMP levels in human lymphocytes. Biochem. Pharmacol. 2003, 65, 193-208. [CrossRef]

45. Alfonso, A.; Alfonso, C. Pharmacology and mechanism of action: Biological detection. In Seafood and Freshwater Toxins: Pharmacology, Physiology, and Detection, 2nd ed.; Botana, L.M., Ed.; Taylor and Francis Group: Boca Raton, FL, USA, 2008; pp. 315-327.

46. Alfonso, A.; Vale, C.; Vilariño, N.; Rubiolo, J.; Louzao, C.; Vieytes, M.R.; Botana, L.M. Recent developments on the mechanism of action of marine phycotoxins. In Proceedings of 17th Meeting on Toxinology, Paris, France, 2-3 December 2009; pp. 51-56.

47. Pazos, M.; Alfonso, A.; Vieytes, M.; Yasumoto, T.; Botana, L. Resonant mirror biosensor detection method based on yessotoxin-phosphodiesterase interactions. Anal. Biochem. 2004, 335, 112-118. [CrossRef] [PubMed]

48. Pazos, M.; Alfonso, A.; Vieytes, M.; Yasumoto, T.; Botana, L. Study of the interaction between different phosphodiesterases and yessotoxin using a resonant mirror biosensor. Chem. Res. Toxicol. 2006, 19, 794-800. [CrossRef] [PubMed]

49. Pazos, M.J.; Alfonso, A.; Vieytes, M.R.; Yasumoto, T.; Botana, L.M. Kinetic analysis of the interaction between yessotoxin and analogs and immobilized phosphodiesterases using a resonant mirror optical biosensor. Chem. Res. Toxicol. 2005, 18, 1155-1160. [CrossRef] [PubMed]

50. Fonfria, E.S.; Vilarino, N.; Vieytes, M.R.; Yasumoto, T.; Botana, L.M. Feasibility of using a surface plasmon resonance-based biosensor to detect and quantify yessotoxin. Anal. Chim. Acta 2008, 617, 167-170. [CrossRef] [PubMed]

51. Alfonso, C.; Alfonso, A.; Vieytes, M.R.; Yasumoto, T.; Botana, L.M. Quantification of yessotoxin using the fluorescence polarization technique, and study of the adequate extraccion procedure. Anal. Biochem. 2005, 344, 266-274. [CrossRef] [PubMed]

52. Livigni, A.; Scorziello, A.; Agnese, S.; Adornetto, A.; Carlucci, A.; Garbi, C.; Castaldo, I.; Annunziato, L.; Avvedimento, E.V.; Feliciello, A. Mitochondrial AKAP121 links cAMP and src signaling to oxidative metabolism. Mol. Biol. Cell 2006, 17, 263-271. [CrossRef] [PubMed]

53. Omori, K.; Kotera, J. Overview of PDEs and their regulation. Circ. Res. 2007, 100, 309-327. [CrossRef] [PubMed]

54. Feliciello, A.; Gottesman, M.E.; Avvedimento, E.V. The biological functions of A-Kinase anchor proteins. J. Mol. Biol. 2001, 308, 99-114. [CrossRef] [PubMed]

55. Fernández-Araujo, A.; Tobio, A.; Alfonso, A.; Botana, L.M. Role of AKAP 149-PKA-PDE4A complex in cell survival and cell differentiation processes. Int. J. Biochem. Cell Biol. 2014. in press.

56. Alonso, E.; Vale, C.; Vieytes, M.R.; Botana, L.M. Translocation of PKC by yessotoxin in an in vitro model of Alzheimer's disease with improvement of tau and beta-amyloid pathology. ACS Chem. Neurosci. 2013, 4, 1062-1070. [CrossRef] [PubMed] 
57. Martín-López, A.; Gallardo-Rodríguez, J.; Sánchez-Mirón, A.; García-Camacho, F.; Molina-Grima, E. Immunoregulatory potential of marine algal toxins yessotoxin and okadaic acid in mouse T lymphocyte cell line EL-4. Toxicol. Lett. 2011, 207, 167-172. [CrossRef] [PubMed]

58. Fernandez-Araujo, A.; Alfonso, A.; Vieytes, M.R.; Botana, L.M. Yessotoxin activates cell death pathways independent of Protein Kinase C in K-562 human leukemic cell line. Toxicol. Vitro 2015, 29, 1545-1554. [CrossRef] [PubMed]

59. Malaguti, C.; Ciminiello, P.; Fattorusso, E.; Rossini, G.P. Caspase activation and death induced by yessotoxin in HeLa cells. Toxicol. Vitro 2002, 16, 357-363. [CrossRef]

60. Korsnes, M.S.; Hetland, D.L.; Espenes, A.; Aune, T. Induction of apoptosis by YTX in myoblast cell lines via mitochondrial signalling transduction pathway. Toxicol. Vitro 2006, 20, 1419-1426. [CrossRef] [PubMed]

61. Malagoli, D.; Marchesini, E.; Ottaviani, E. Lysosomes as the target of yessotoxin in invertebrate and vertebrate cell lines. Toxicol. Lett. 2006, 167, 75-83. [CrossRef] [PubMed]

62. Callegari, F.; Rossini, G.P. Yessotoxin inhibits the complete degradation of E-cadherin. Toxicology 2008, 244, 133-144. [CrossRef] [PubMed]

63. Ronzitti, G.; Rossini, G.P. Yessotoxin induces the accumulation of altered E-cadherin dimers that are not part of adhesive structures in intact cells. Toxicology 2008, 244, 145-156. [CrossRef] [PubMed]

64. Young, C.; Truman, P.; Boucher, M.; Keyzers, R.; Northcote, P.; Jordan, W.T. The algal metabolite yessotoxin affects heterogeneus nuclear ribonucleoproteins in HepG2 cells. Proteomics 2009, 9, 2529-2542. [CrossRef] [PubMed]

65. Fernandez-Araujo, A.; Sanchez, J.A.; Alfonso, A.; Vieytes, M.R.; Botana, L.M. Different toxic effects of YTX in tumor K-562 and lymphoblastoid cell lines. Front. Pharmacol. 2015, 6. [CrossRef] [PubMed]

66. Korsnes, M.S.; Espenes, A. Yessotoxin as an apoptotic inducer. Toxicon 2011, 57, 947-958. [CrossRef] [PubMed]

67. Fernandez-Araujo, A.; Alfonso, A.; Vieytes, M.R.; Botana, L.M. Key role of phosphodiesterase 4A (PDE4A) in autophagy triggered by yessotoxin. Toxicology 2015, 329, 60-72. [CrossRef] [PubMed]

68. Rubiolo, J.A.; Lopez-Alonso, H.; Martinez, P.; Millan, A.; Cagide, E.; Vieytes, M.R.; Vega, F.V.; Botana, L.M. Yessotoxin induces ER-stress followed by autophagic cell death in glioma cells mediated by mTOR and BNIP3. Cell Signal. 2014, 26, 419-432. [CrossRef] [PubMed]

69. Korsnes, M.S.; Roed, S.S.; Tranulis, M.A.; Espenes, A.; Christophersen, B. Yessotoxin triggers ribotoxic stress. Toxicol. Vitro 2014, 28, 975-981. [CrossRef] [PubMed]

70. Korsnes, M.S.; Espenes, A.; Hetland, D.L.; Hermansen, L.C. Paraptosis-like cell death induced by yessotoxin. Toxicol. Vitro 2011, 25, 1764-1770. [CrossRef] [PubMed]

71. Korsnes, M.S.; Espenes, A.; Hermansen, L.C.; Loader, J.I.; Miles, C.O. Cytotoxic responses in BC3H1 myoblast cell lines exposed to 1-desulfoyessotoxin. Toxicol. Vitro 2013, 27, 1962-1969. [CrossRef] [PubMed]

72. Korsnes, M.S. Yessotoxin as a tool to study induction of multiple cell death pathways. Toxins 2012, 4, 568-579. [PubMed]

73. Botana, L.M.; Alfonso, A.; Vale, C.; Vilariño, N.; Rubiolo, R.; Alonso, E.; Cagide, E. The mechanistic complexities of phycotoxins: Toxicology of azaspiracids and yessotoxins. In Advances in Molecular Toxicology; Fishbein, J.C., Heilman, J., Eds.; Elsevier: Philadelphia, PA, USA, 2014; Volume 8, pp. 1-26.

74. Ares, I.R.; Louzao, M.C.; Vieytes, M.R.; Yasumoto, T.; Botana, L.M. Actin cytoskeleton of rabbit intestinal cells is a target for potent marine phycotoxins. J. Exp. Biol. 2005, 208 Pt 22, 4345-4354. [CrossRef] [PubMed]

75. Botana, L.M.; Alfonso, A.; Vieytes, M.R.; Loza, M.I. Therapeutic Use of Yessotoxin as Human Tumor Cell Growth Inhibitor. European Patent EP1875906 A2, 9 January 2008.

76. Korsnes, M.S.; Korsnes, R. Lifetime distributions from tracking individual BC3H1 cells subjected to Yessotoxin. Front. Bioeng. Biotechnol. 2015, 3. [CrossRef] [PubMed]

77. Küntziger, T.; Rogne, M.; Folstad, R.L.; Collas, P. Association of PP1 with its regulatory subunit AKAP149 is regulated by serine phosphorylation flanking the RVXF motif of AKAP149. Biochemistry 2006, 45, 5868-5877. [CrossRef] [PubMed]

78. Steen, R.L.; Beullens, M.; Landsverk, H.B.; Bollen, M.; Collas, P. AKAP149 is a novel PP1 specifier required to maintain nuclear envelope integrity in G1 phase. J. Cell Sci. 2003, 116, 2237-2246. [CrossRef] [PubMed]

79. Canton, D.A.; Scott, J.D. Anchoring proteins encounter mitotic kinases. Cell Cycle 2013, 12, 863-864. [CrossRef] [PubMed] 
80. Wang, Q.; Chaerkady, R.; Wu, J.; Hwang, H.J.; Papadopoulos, N.; Kopelovich, L.; Maitra, A.; Matthaei, H.; Eshleman, J.R.; Hruban, R.H.; et al. Mutant proteins as cancer-specific biomarkers. Proc. Natl. Acad. Sci. USA 2011, 108, 2444-2449. [CrossRef] [PubMed]

81. Korsnes, M.S.; Hetland, D.L.; Espenes, A.; Aune, T. Cleavage of tensin during cytoskeleton disruption in YTX-induced apoptosis. Toxicol. Vitro 2007, 21, 9-15. [CrossRef] [PubMed]

82. Martín-López, A.; Gallardo-Rodríguez, J.; Sánchez-Mirón, A.; García-Camacho, F.; Molina-Grima, E. Cytotoxicity of yessotoxin and okadaic acid in mouse T lymphocyte cell line EL-4. Toxicon 2012, 60, 1049-1056. [CrossRef] [PubMed]

83. Leira, F.; Alvarez, C.; Cabado, A.G.; Vieites, J.M.; Vieytes, M.R.; Botana, L.M. Development of a F actin-based live-cell fluorimetric microplate assay for diarrhetic shellfish toxins. Anal. Biochem. 2003, 317, 129-135. [CrossRef]

84. Rios-Doria, J.; Day, M.L. Truncated E-cadherin potentiates cell death in prostate epithelial cells. Prostate 2005, 63, 259-258. [CrossRef]

85. Pierotti, S.; Albano, C.; Milandri, A.; Callegari, F.; Poletti, R.; Rossini, G.P. A slot blot procedure for the measurement of yessotoxins by a functional assay. Toxicon 2007, 49, 36-45. [CrossRef] [PubMed]

86. Ronzitti, G.; Callegari, F.; Malaguti, C.; Rossini, G.P. Selective disruption of the E-cadherin-catenin system by an algal toxin. Br. J. Cancer 2004, 90, 1100-1107. [CrossRef] [PubMed]

87. Ferrari, S.; Ciminiello, P.; Dell'Aversano, C.; Forino, M.; Malaguti, C.; Tubaro, A.; Poletti, R.; Yasumoto, T.; Fattorusso, E.; Rossini, G.P. Structure-activity relationships of yessotoxins in cultured cells. Chem. Res. Toxicol. 2004, 17, 1251-1257. [CrossRef] [PubMed]

88. Callegari, F.; Sosa, S.; Ferrari, S.; Soranzo, M.R.; Pierotti, S.; Yasumoto, T.; Tubaro, A.; Rossini, G.P. Oral administration of yessotoxin stabilizes E-cadherin in mouse colon. Toxicology 2006, 227, 145-155. [CrossRef] [PubMed]

89. Orsi, C.F.; Colombari, B.; Callegari, F.; Todaro, A.M.; Ardizzoni, A.; Rossini, G.P.; Blasi, E.; Peppoloni, S. Yessotoxin inhibits phagocytic activity of macrophages. Toxicon 2010, 55, 265-273. [CrossRef] [PubMed]

90. Malagoli, D.; Casarini, L.; Sacchi, S.; Ottaviani, E. Stress and immune response in the mussel Mytilus galloprovincialis. Fish Shellfish Immunol. 2007, 23, 171-177. [CrossRef] [PubMed]

91. Malagoli, D.; Ottaviani, E. Yessotoxin affects fMLP-induced cell shape changes inMytilus galloprovincialis immunocytes. Cell Biol. Int. 2004, 28, 57-61. [CrossRef] [PubMed]

92. Alfonso, A.; Cabado, A.G.; Vieytes, M.R.; Botana, L.M. Functional compartments in rat mast cells for cAMP and calcium on histamine release. Cell Signal. 2000, 12, 343-350. [CrossRef]

93. Botana, L.M.; Alfonso, A.; Vieytes, M.R.; Loza, M.I. Use of Yessotoxin in the Treatment of Allergic and Asthmatic Processes. European Patent EP1875907 A2, 9 January 2008.

94. Cole, G.; Dobkins, K.R.; Hansen, L.A.; Terry, R.D.; Saitoh, T. Decreased levels of protein kinase C in Alzheimer brain. Brain Res. 1988, 452, 165-174. [CrossRef]

95. Botana, L.M.; Alonso, E.; Vale, C. Use of Yessotoxin and Analogs and Derivatives thereof for Treating and/or Preventing Neurodegenerative Diseases Linked to Tau and Beta Amyloid. European Patent 2011739430, 19 December 2012; U.S. Patent 13577537, 7 February 2013.

96. Botana, L.M.; Lopez-Alonso, H.; Rubiolo, J. Use of Yessotoxins and the Derivatives thereof for the Treatment and/or Prevention of Metabolic Diseases. Patent WO2012140298 A1, 18 October 2012.

(c) 2016 by the authors; licensee MDPI, Basel, Switzerland. This article is an open access article distributed under the terms and conditions of the Creative Commons by Attribution (CC-BY) license (http:/ / creativecommons.org/licenses/by/4.0/). 